\title{
IAMJ
}

INTERNATIONAL

AYURVEDIC

MEDICAL JOURNAL

ISSN: 23205091

Impact Factor: 5.344

\section{AYURVEDIC MANAGEMENT OF MENIERE'S DISEASE: A CASE REPORT}

\section{Bhoomi Mehta ${ }^{1}$, Shraddha Chaudhary ${ }^{2}$, D. B. Vaghela ${ }^{3}$}

${ }^{1}$ P.G. Scholar, Shalakya Tantra Department,

${ }^{2}$ P.G. Scholar, Shalakya Tantra Department,

${ }^{3} \mathrm{I} / \mathrm{C}$ HOD \& Associate Professor,

Department of Shalakya Tantra, IPGT \& RA, GAU, Jamnagar, Gujarat, India

Email: bhumimehtaamreli@gmail.com

https://doi.org/10.46607/iamj0807322020

(Published online: July 2020)

Open Access

(C) International Ayurvedic Medical Journal, India 2020

Article Received: 19/06/2020 - Peer Reviewed: 25/06/2020 - Accepted for Publication: 01/07/2020

Check for updates

\begin{abstract}
Meniere's disease is a disorder of internal ear, in which endolymphatic system is distended with endolymph. It is characterized by vertigo, sensory neural hearing loss, tinnitus and aural fullness. Bhrama, Karnaksweda, Karnanada, Karnabadhirya can be compared with Meniere's disease symptomatically. However, it is not possible to compare Meniere's diseases with any Ayurvedic disease. Here treatment protocol used was Dhanvayas Kwatha, Punarnavashtaka Kwatha, Eranda Bhrusta Haritaki internally with Ksheera Bala Taila Nasya and Asanbilwadi Taila Karnapoorana. After 3 months of treatment patient got relief from vertigo and tinnitus and mild hearing loss persist. Hence the single case report shows that Ayurvedic management of Meniere's disease gives excellent result.
\end{abstract}

Keyword: Asanbilwadi Taila Karnapoorana, Dhanvayas Kwatha, Ksheera Bala Taila Nasya, Punarnavasthaka Kwatha. 


\section{INTRODUCTION}

Meniere's disease, also called endolymphatic hydrops. It is a disorder of internal ear, in which endolymphatic system is distended with endolymph. It is characterized by vertigo, sensory neural hearing loss, tinnitus and aural fullness ${ }^{1}$. The main pathology in Meniere's disease is distention of endolymphatic system due to increased volume of endolymph. This can be result either from increased production of endolymph or faulty absorption of endolymph or both. The exact cause of Meniere's disease is not yet known. Potential etiological or precipitating conditions include genetic variations, infection, vascular risk factors, diet, allergy, autonomic, endocrine and autoimmune factors. In this disease, symptoms occur at irregular and unpredictable intervals. Vertigo comes in attacks; with sudden onset and patient have feeling of rotation of himself or his environment. Hearing loss usually accompanies vertigo and it improves after attack and may be normal during the period of remission but after recurrent attacks some hearing loss is permanent. Tinnitus is low pitched type and is aggravated during acute attack $^{2}$. The annual incidence of Meniere's disease is 5-7 / 10,000. Disease is common in middle age group. In the differential diagnosis of Meniere's disease, vestibular migraine, vestibular paroxysmia and chronic subjective dizziness have to be considered. To exclude these Meniere's like diseases full clinical examination of the head and neck region (including vestibular examination), liminal and speech audiometry, tympanometry, multidetector computed tomography (CT scan) of the temporal bone, MRI of the posterior fossa (with intravenous injection of gadolinium), blood analysis (haematology, thyroid, biochemical and genetic testing). The posterior fossa MRI with intravenous administration of gadolinium is the most sensitive examination to exclude cerebellopontine angle and inner ear pathology (in the absence of any contraindications to MRI).

Treatment in the modern science for this is disease is conservative management only and generally is treated with counseling for dietary restrictions, drug therapy and surgical interventions to prevent recurrence of vertigo. Hearing loss is treated by hearing aids, bone- conduction implants for unilateral deafness and cochlear implantation in cases of bilateral profound hearing loss.

According to Ayurvedic text Bhrama, Karnaskweda, Karnanada, Karnabadhirya can be compared with Meniere's disease symptomatically. However, it is not possible to compare Meniere's diseases with any Ayurvedic disease. Shrotrendriya is seat of Vayu and Akasha Mahabhuta. So, Vata Shamaka Dravya should be used. In Bhrama there is vitiation of Vata Pitta Dosha ${ }^{3}$, So Vata Pitta Shamaka treatment should be given. There is an accumulation of endolymph in the membranous labyrinth, thus in the modern pharmacology diuretics are recommended and salt restriction is advised. Hence in the management of Meniere's disease Shothaghna, Mutraladravya Prayoga if given therapeutically and if Vishyandakaraka, Kledajanaka Dravyas like Samudra Lavana are restricted, clinical improvement will be necessarily noticed.

\section{CASE REPORT}

A 26-year female patient come to OPD of Shalakya Tantra Department with the chief complain of episodic vertigo associated with Tinnitus and Hearing loss since 9 months.

\section{History of present illness:-}

Patient was well before 9 months. Gradually she started suffering from episodic vertigo (several times in a day) and hearing to loud sound also cause episode of vertigo, continuous tinnitus and hearing loss, during every attack tinnitus and hearing increase. So, she consults to modern doctor, but no relief was found, So she came for Ayurvedic treatment.

History of past illness:- There was no relevant past history of any other disease.

Family History:- No any positive family history was found.

\section{Personal History: -}

Diet:- Vegetarian, Appetite: Moderate, Bowel: Constipated, Micturition: Normal, Sleep: Disturbed, Addiction- No addiction. All vital signs and general physical examination were found to be within normal limit. 


\section{Astavidha Pariksha:-}

\begin{tabular}{|l|l|}
\hline 1)Nadi & Sama \\
\hline 2)Shabda & Prakrita \\
\hline 3)Sparsha & Ruksha \\
\hline 4)Akriti & Madhyama \\
\hline 5)Jihva & Nirama \\
\hline 6)Mala & Vibandha \\
\hline 7)Mutra & Samyaka \\
\hline 8)Drika & Aprakrita \\
\hline
\end{tabular}

Occupational History:- Patient was housewife Diagnosis:- When patient came to OPD of Shalakya Tantra, she has already done audiogram before 4 month and findings in audiogram was left ear moderate sensory neural hearing loss and right ear normal hearing. SISI Test was carried out at $1 \mathrm{khz}$ and $4 \mathrm{khz}$ and it has left ear $100 \%$ cochlear sensitivity and right ear $0 \%$ cochlear sensitivity. Audiogram was repeated

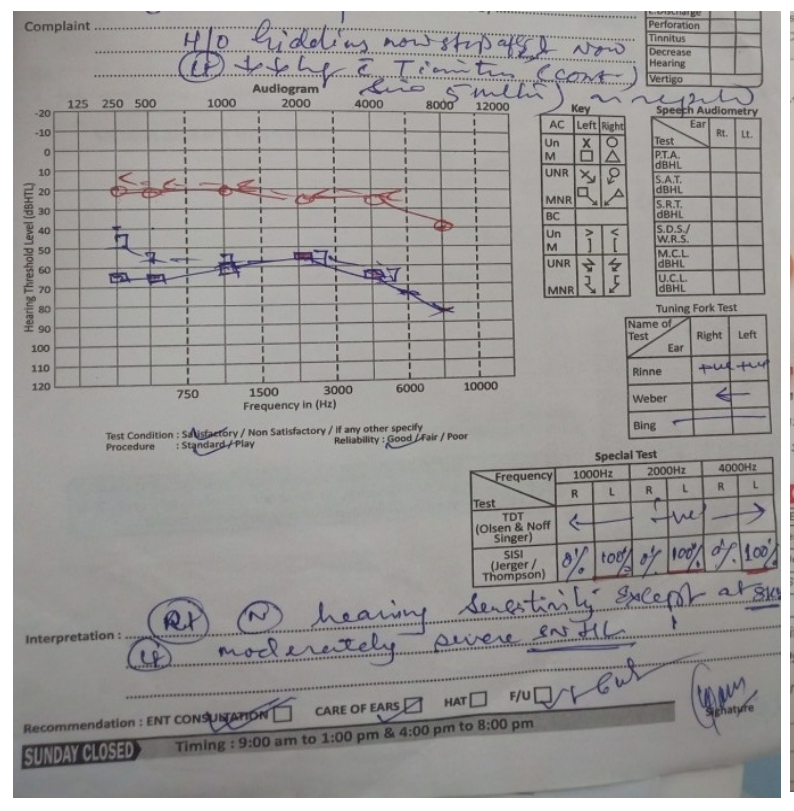

Treatment Protocol: See Table No. 1

Pathya - Apathya:- Avoid loud noise and using headphones. Use salt restricted diet.

\section{Observation and Result:-}

There was significant improvement in episodes of vertigo ( 1 time in a day) after treatment of 1 month. After 2 month of treatment no continuous tinnitus was present and severity was decreased, and 2-3 episodes of on 10/01/2020 and findings were left ear sensory neural moderate hearing loss with slopping at high frequency and right ear normal hearing. SISI Test was carried out at $1 \mathrm{khz}$ and $4 \mathrm{khz}$ and it has left ear $100 \%$ cochlear sensitivity and right ear $10 \%$ cochlear sensitivity. Dix Hallpike Manoeuvre was done, and result was negative. After assessing the causes and symptoms, patient was diagnosed as Meniere's Disease.

\section{On Examination:-}

Ear Examination:- Normal

Nose Examination: - Normal

Throat Examination: - Normal

Audiogram:- Left ear moderate sensory neural hearing loss slopping at high frequency.

Right ear normal hearing.

SISI:- Left ear - $100 \%$ Cochlear sensitivity at $1 \mathrm{khz}$ and $4 \mathrm{khz}$

Right ear- $10 \%$ Cochlear Sensitivity at $1 \mathrm{khz}$ and $4 \mathrm{khz}$

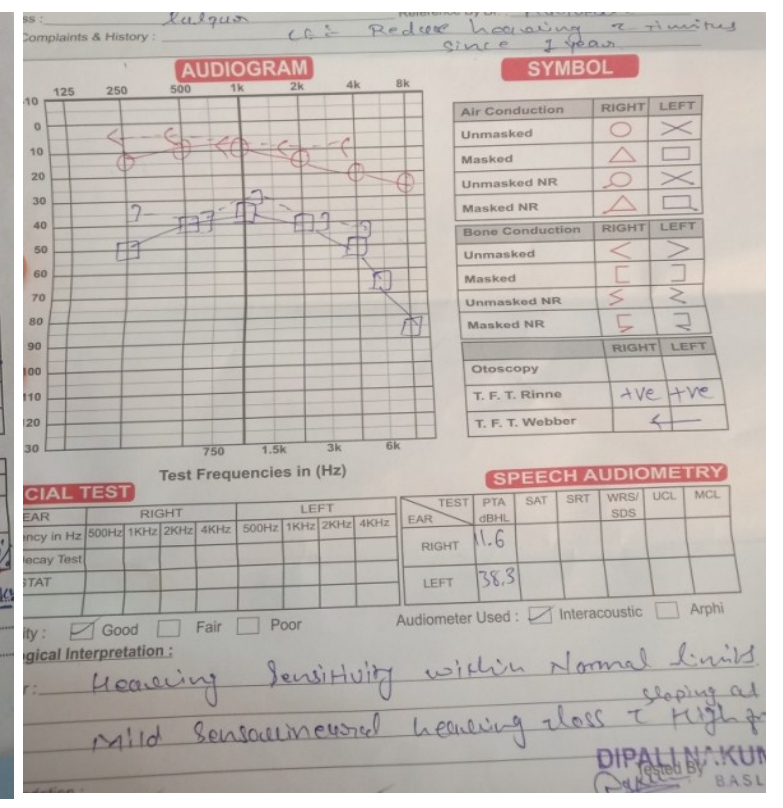

vertigo per week. After 3 months no complaint of vertigo and no tinnitus was there, and minimal sensory neural hearing loss was there. SISI Test was normal.

\section{DISCUSSION}

Ayurvedic management of Meniere's disease is based on Chikitsha of Bhrama and Karnaroga, where there is vitiation of Vata-Pitta Dosha in Bhrama, and Karna 
being one of the Adhisthana of Vata Dosha $a^{4}$ So, mainly here Vata-Pitta Shamana drugs are used., Snehana becomes important to control the localized vitiation of Vata Dosha. Hence, Karnapoorana was selected in the management of the disease. The use of Sneha specially Taila helps to subside Vata Dosha and clears the Srotasa of the Karna. In Sahastrayogama, Asanbilwadi Taila is indicated in Karnaroga. So, putting that concern here Asanabilwadi Taila was given for Karnapoorana. Nasya is the main procedure for Shiro Shodhana, it will clean the deep seated dhoshas from Karna, for that purpose Nasya was selected here. Acharya Vagabhatta has described Ksheera Bala Taila in Vata-Rakta Rogadhikar ${ }^{6}$; it contains Ksheera which is Pitta Shamaka and Bala having Vata Shamaka properties, so it was chosen for Nasya. Dhanvayasha Kwatha having Pitta Shamaka properties and is mention by Acharya Chakradatta in Bhrama Rogadhikara ${ }^{7}$, So it was given orally. Punarnavadi Kwatha is having Mutrala properties and Shothaghana properties, so it is used to reduce endolymphatic hydrops. So, given orally before meal. Eranda Bhrushta Haritaki was given for Vatanuloma$n a$ and Kosthasodhana. All these above factors will ultimately lead to relieve the symptoms of Meniere's disease. No adverse reaction was observed during the trail and after the treatment.

\section{CONCLUSION}

This case report concludes that Ayurvedic management with Nasya and Karnapoorana procedure along with internal medicine i.e. Punarnavadi Kwatha, Dhanvayasa Kwatha and Eranda Bhrushta Haritaki offers good result in the treatment of Meniere's disease.

\section{REFERENCES}

1. P L Dhingra. Disease of Ear, Nose, and Throat. $6^{\text {th }}$ edition. p.100

2. P L Dhingra. Disease of Ear, Nose, and Throat. $6^{\text {th }}$ edition. p. 100

3. Shastri Ambikadutta, editor of Ayurveda Tattva Sandipika, Hindi Commentary on Sushruta Samhita, Chaukhambha Sanskrit Prakashana, Varanasi Reprint, 2015 Uttartantra 20/3,4,5.
4. Sarvanga Sundri, editor, Hindi Commentary on Astanga Hridayam of Srimad Vagbhatt, Chaukhambha Sanskrit Prakashana, Varanasi Reprint, 2007 Sutrasthan. Ch.12/1

5. Sahasrayoga, Taiayogaprakarana 45

6. Sarvanga Sundri, editor, Hindi Commentary on Astanga Hridayam of Srimad Vagbhatt, Chaukhambha Sanskrit Prakashana, Varanasi Reprint,2007 Chikitshasthan. Ch.29/45-46

7. Dr. Indradev Tripathi, editor of Chakrdatta Chaukhambha Sanskrit Prakashana, Varanasi Reprint, 2018 Chikitsha Rogadhikara, Ch. 17/8-9

\section{Source of Support: Nil}

\section{Conflict of Interest: None Declared}

How to cite this URL: Bhoomi Mehta et al: Ayurvedic Management of Meniere's Disease: A Case Report. International Ayurvedic Medical Journal \{online\} 2020 \{cited July, 2020\} Available from: http://www.iamj.in/posts/images/upload/4015_4018.pdf 